\title{
ANALISIS DETERMINAN ISLAMICITY PERFORMANCE INDEX PADA BANK UMUM SYARIAH DI INDONESIA
}

\author{
Kristianingsih $^{1}$, Mahesa Dava Wardhana ${ }^{2}$ Setiawan $^{3}$ \\ ${ }^{1,2,3}$ Akuntansi, Politeknik Negeri Bandung, Indonesia \\ Email Korespondensi: mahesa.dava.ksy17@polban.ac.id
}

\begin{abstract}
Islamicity Performance Index (IPI) is a model developed to measure the performance of Islamic banks with a socio-economic approach. This study reveals the factors that affect the Islamicity Performance Index (IPI) which is represented by the Profit Sharing Financing Ratio (PSR) index. With a sample of 12 Islamic Commercial Banks (BUS) in Indonesia, this study uses static and dynamic panel data analysis. The data used is secondary data derived from the annual financial statements of each BUS. The results showed a significant positive effect of TPF and FDR on PSR in the static and dynamic models, significant negative NPF on PSR in the static model, significant positive NPF on PSR in the dynamic model, insignificant negative BOPO on PSR in the static model, positive insignificant BOPO on PSR in the dynamic model, significant positive PSR (-1) on PSR in the dynamic model. Simultaneously the independent variable is able to explain the dependent variable by $95.8 \%$.
\end{abstract}

Keywords: Islamicity Performance Index, Profit Sharing Financing Ratio, Islamic Bank.

\begin{abstract}
Abstrak: Islamicity Performance Index (IPI) adalah model yang dikembangkan untuk mengukur kinerja bank syariah dengan pendekatan socio-economic. Penelitian ini mengungkapkan faktorfaktor yang mempengaruhi Islamicity Performance Index (IPI) yang diwakilkan dengan indeks Profit Sharing Financing Ratio (PSR). Dengan sampel 12 Bank Umum Syariah (BUS) di Indonesia, penelitian ini menggunakan teknik analisis data panel statis dan dinamis. Data yang digunakan adalah data sekunder yang berasal dari laporan keuangan tahunan masing-masing BUS. Hasil penelitian menunjukan pengaruh positif signifikan DPK dan FDR terhadap PSR pada model statis dan dinamis, negatif signifikan NPF terhadap PSR pada model statis, positif signifikan NPF terhadap PSR pada model dinamis, negatif tidak signifikan BOPO terhadap PSR pada model statis, positif tidak signifikan BOPO terhadap PSR pada model dinamis, postif signifikan PSR(-1) terhadap PSR pada model dinamis. Secara simultan variabel bebas mampu menjelaskan variabel terikat sebesar 95,8\%.
\end{abstract}

Kata Kunci: Islamicity Performance Index, Profit Sharing Financing Ratio, Bank Syariah. 


\section{PENDAHULUAN}

Perbankan syariah adalah bentuk gabungan sindikasi dengan prinsip-prinsip hukum islam sebagai landasan fundamentalnya serta memiliki ruang etika bisnis yang lengkap (Presendorfer \& Lehner, 2016). Meskipun hanya terpusat di kawasan Asia Selatan, Timur Tengah, dan Asia tenggara, perbankan syariah telah diadopsi oleh negara-negara barat sebagai perantara untuk pasar konsumen muslim maupun non-muslim. Eksistensi bank syariah di dunia internasional telah membuktikan bahwa bank syariah mampu berkontribusi pada pasar keuangan global (Khan \& Bhatti, 2008).

Indonesia adalah salah satu potensi besar bagi industri keuangan syariah khususnya dalam bidang perbankan syariah. Menurut riset Global Religious Future, jumlah muslim Indonesia sampai akhir 2020 diprediksi mencapai 229.62 juta jiwa dan akan meningkat menjadi 245.02 juta jiwa 10 tahun kedepan (Hackett dkk., 2015). Potensi jumlah muslim yang begitu besar ini berdampak kepada perkembangan industri syariah di Indonesia. Berdasarkan Laporan Islamic Finance Country Index (IFCI) tahun (IFCI, 2019), Indonesia menempati ranking pertama sebagai negara dengan kinerja perbankan dan keuangan syariah terbaik di dunia. Hal ini menjadi indikator kemajuan perbankan dan keuangan syariah nasional di kancah internasional. Hingga saat ini, kontribusi terbesar pada indikator perkembangan perbankan syariah nasional dicapai oleh Bank Umum Syariah (BUS). BUS mencatatkan peningkatan nilai aset dan pembiayaan yang disalurkan selama beberapa tahun terakhir ini. Selain itu, Peningkatan aset bank syariah serta jumlah pembiayaan disalurkan menunjukkan hasil positif dengan pertumbuhan setiap tahunnya. Hal ini mengindikasi perkembangan yang cukup baik dan berdampak kepada perekonomian Indonesia (Ayyubi dkk., 2017).

Kendati demikian, Bank Umum Syariah (BUS) bukanlah industri yang hanya mementingkan unsur materialistik saja. Evaluasi kinerja tidak hanya ditekankan kepada kinerja keuangan konvensional semata. Karena pada dasarnya, lembaga keuangan islam memiliki peranan serta tanggung jawab yang tidak berfokus hanya pada kebutuhan para pemangku kepentingan, melainkan harus menjalankan bisnis sesuai dan searah dengan Sharia Compliance. Dalam bisnis perbankan syariah, Sharia Compliance adalah salah satu dari sekian banyak kunci untuk mendapatkan kepercayaan tinggi dari masyarakat akan besarnya pasar keuangan syariah di Indonesia (R. Setyowati, 2017).

Hameed dkk. (2004) melakukan pengembangan suatu model untuk evaluasi kinerja keuangan perbankan islam yang dinamakan sebagai Islamicity Performance Index (IPI). Menurutnya, tujuan bisnis utama dalam bank syariah adalah profit sharing financing yang diukur dengan jumlah pembiayaan bagi hasil yaitu mudharabah serta musyarakah pada total penyaluran pembiayaan. Pembiayaan tersebut menjadi tolak ukur yang sangat penting dalam bisnis perbankan syariah karena sistem tersebut lebih adil dan menjadi akad yang terbaik pada perbankan syariah (Mannan, 1989). Namun ditengah kemajuan industri perbankan nasional, pembiayaan bagi hasil masih belum menjadi proporsi utama dalam pelaksanaannya khususnya pada bank umum syariah di Indonesia. 


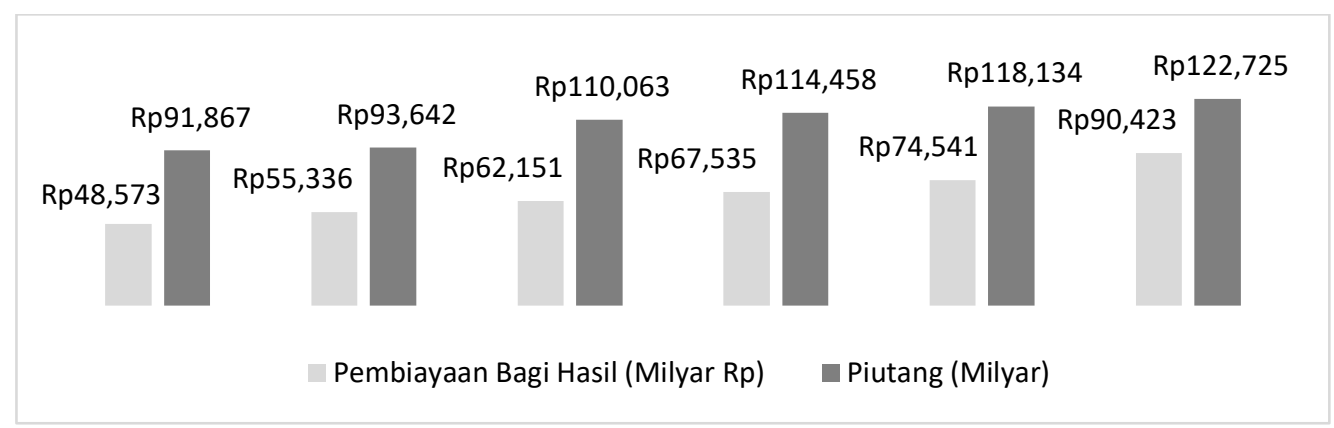

Sumber: Statistik Perbankan Syariah OJK (2020)

Gambar 1.

Perbandingan Pembiayaan Bagi Hasil BUS 2014-2019

Pada umumnya, penerapan IPI melalui profit sharing financing di negara-negara mayoritas muslim seperti Bangladesh, Malaysia, Pakistan, Sudan, serta Indonesia juga menunjukkan hasil dengan pertumbuhan positif setiap tahunnya, meskipun pada realitanya pembiayaan musyarakah dan mudharabah ini belum mendapatkan porsi lebih tinggi dari pembiayaan lainnya (Abdul Razak \& Abdul-Wahab, 2018).

Penelitian terdahulu telah menemukan faktor apa saja yang mempengaruhi pembiayaan bagi hasil seperti Dana Pihak Ketiga (DPK), Non Performing Financing (NPF), dan Financing to Deposit Ratio (FDR) (Aprilia \& Mahardika, 2019; Lisa, 2017; Murni dkk., 2018; Salamah \& Kusumaningtias, 2019). Secara garis besar, penelitian-penelitian tersebut telah menguji pengaruh positif DPK dan FDR serta pengaruh negatif NPF terhadap pembiayaan bagi hasil. Meskipun ada perbedaan hasil pada penelitian Aprilia \& Mahardika (2019) dan Murni dkk. (2018) dimana NPF tidak berpengaruh pada pembiayaan bagi hasil atau profit sharing financing, serta penelitian Salamah \& Kusumaningtias (2019) dimana FDR tidak memiliki pengaruh terhadap profit sharing financing ratio. Pada statistik perbankan syariah OJK, terlihat terjadi peningkatan pertumbuhan pembiayaan bagi hasil BUS pada tahun 2019 yang diikuti dengan nilai penurunan FDR. Selanjutnya terjadi peningkatan pertumbuhan DPK ditahun 2017 yang diikuiti dengan perlambatan pertumbuhan pembiayaan bagi hasil. Hal ini tentunya menimbulkan berbagai spekulasi mengenai peran DPK dan FDR dalam meningkatkan pembiayaan bagi hasil. Meskipun hal ini mungkin saja dipengaruhi oleh peningkatan NPF di tahun yang sama yang dalam artian bertentangan dengan penelitian Aprilia \& Mahardika (2019) dan Murni dkk. (2018).

Tabel 1

Pertumbuhan DPK, FDR, NPF, dan Pembiayaan Bagi Hasil BUS 2015-2019

\begin{tabular}{|c|c|c|c|c|c|}
\hline Tahun & 2015 & 2016 & 2017 & 2018 & 2019 \\
\hline Pertumbuhan Pembiayaan Bagi Hasil (\%) & $14 \%$ & $12 \%$ & $9 \%$ & $10 \%$ & $21 \%$ \\
\hline Pertumbuhan DPK (\%) & $6 \%$ & $-11 \%$ & $15 \%$ & $8 \%$ & $12 \%$ \\
\hline Pertumbuhan ROA (\%) & $20 \%$ & $29 \%$ & $0 \%$ & $103 \%$ & $35 \%$ \\
\hline Pertumbuhan NPF (\%) & $-6 \%$ & $-32 \%$ & $18 \%$ & $-24 \%$ & $-4 \%$ \\
\hline Pertumbuhan FDR (\%) & $2 \%$ & $-2 \%$ & $-7 \%$ & $-1 \%$ & $-1 \%$ \\
\hline
\end{tabular}

Sumber: Statistik Perbankan Syariah OJK (2020) 
Berdasarkan hal tersebut, penulis mencoba mengamati serta mengembangkan berbagai faktor yang memengaruhi pembiayaan bagi hasil yaitu DPK, FDR, dan NPF dengan pendekatan profit sharing financing ratio yang merupakan indikator Islamicity Performance Index (IPI). Penelitian-penelitian sebelumnya telah banyak berfokus pada determinan volume pembiayaan bagi hasil, sehingga pembaharuan penelitian akan dikembangkan dengan variabel IPI yaitu profit sharing financing ratio serta menguji pengaruh efisiensi pada perbankan yakni Biaya Operasional Pendapatan Operasional (BOPO) dimana pada studi sebelumnya juga terbukti berpengaruh terhadap volume pembiayaan maupun pembiayaan bagi hasil (Andriyanto \& Prastika, 2018).

\section{TINJAUAN PUSTAKA}

\subsection{Islamicity Performance Index (IPI)}

Model alternatif dalam mengukur kinerja pada lembaga keuagan syariah khususnya perbankan syariah telah digagas oleh Hameed et al. (Hameed dkk., 2004). Dalam modelnya, diusulkan dengan apa yang dinamakan sebagai Islamicity Indices yang dibagi menjadi dua jenis, yaitu Islamicity Disclosure Index serta Islamcity Quantitative Index atau dikenal dengan sebutan Islamicity performance Index (IPI). IPI mengevaluasi berdasarkan analisis keuangan yang terdiri dari indicator: Islamic Investment vs Non-Islamic Investment, Islamic Income vs Non-Islamic Income, Directors-Employees Welfare Rasio, Equitable Distribution Rasio, Zakat Performance Rasio, dan AAOIFI Indeks dan Profit Sharing Financing Ratio. Indikator-indikator yang diterapkan ini berdiri sendiri dan tidak terikat satu sama lain.

Evaluasi analisis keuangan bank syariah melalui media laporan keuagan menjadi hal penting karena menggambarkan kinerja yang sesungguhnya dan posisi perusahaan ditahun yang bersangkutan (Ganga dkk., 2015). Islamicity Performance Idex (IPI) menawarkan perhitungan yang sederhana dan praktis untuk diaplikasikan. Aspek-aspek yang diterapkan adalah pembiayaan bagi hasil, zakat, keseimbangan distribusi, kesejahteraan pegawai, pendapatan dan investasi halal, serta kepatuhan akuntansi. Dalam aplikasinya di lapangan, belum semua bank syariah di Indonesia mampu melaksanakan setiap aspek kinerja keuangan dalam IPI.

\subsection{Profit Sharing Financing}

Profit Sharing Financing atau pembiayaan berbasis bagi hasil adalah pembiayaan yang berasal dari kegiatan operasional antara bank syariah dengan penerima pembiayaan yang didasari atas pembagian keuntungan dan kerugian yang didapat secara adil sesuai akad mudharabah atau musyarakah. Pembiayaan berbasis bagi hasil seharusnya dijadikan sebagai pembiayaan utama bagi bank syariah disamping pembiayaan lain karena pembiayaan bagi hasil adalah representasi dari bank syariah sesungguhnya (Ascarya \& Yumanita, 2006). Keutamaan pembiayaan ini dibandingkan pembiayaan lainnya adalah karena adanya pengalokasian sumber daya secara efisien dan menghilangkan konflik antara pihak terlibat sehingga menjadikan bank syariah lebih efisien sebagai lembaga intermediasi (ElBiraika, 1998). Pembiayaan ini terbagi dua, yaitu mudharabah serta musyarakah, sehingga untuk melakukan penilaian kinerja dijumlahkan di antara keduanya dan dibagi total 
pembiaayaan sehingga berbentuk menjadi rasio kinerja pembiayan bagi hasil (Hameed dkk., 2004).

\subsection{Pengembangan Hipotesis}

\subsubsection{Dana Pihak Ketiga}

Dana Pihak Ketiga (DPK) adalah dana dari nasabah yang dihimpun bank untuk menjalankan fungsi bank sebagai lembaga intermediasi. DPK bersumber dari nasabah dan dipercayakan kepada bank atau unit syariah berdasar akad wadi'ah atau lainnya selama tidak dilarang dalam prinsip syariah. DPK dalam bank syariah dihimpun dari giro, tabungan, maupun deposito atau dana investasi yang berlandaskan prinsip syariah (Kinanti \& Purwohandoko, 2017). DPK menjadi faktor utama untuk bank dalam menjalankan fungsi pendanaan serta penyaluran pembiayaan ke sektor-sektor produktif (Harahap, 2017). Sehingga kesimpulannya, Pergerakan nilai DPK pada bank syariah akan memberikan dampak kepada likuiditas dan juga pembiayaan yang diberikan.

Pada penelitian-penelitian sebelumnya, ditemukan bahwa peningkatan nilai DPK akan mempengaruhi kenaikan volume pembiayaan mudharabah dan musyarakah atau akan meningkatkan profit sharing financing ratio (Aprilia \& Mahardika, 2019; Lisa, 2017). Dengan demikian dapat diajukan hipotesis sebagai berikut:

H1: DPK berpengaruh positif signifikan terhadap PSR.

\subsubsection{Risiko Likuiditas}

Risiko likuiditas merupakan kemungkinan kerugian bagi bank syariah yang dapat timbul dari tidak mampunya bank memenuhi kewajiban mereka atau mendanai peningkatan aset saat jatuh tempo tanpa meninggalkan biaya atau kerugian (Islamic Financial Service Board, 2005). Risiko ini sebenarnya muncul akibat ketidakseuaian jatuh tempo dimana kewajiban memiliki jangka waktu lebih pendek dari aset (Ariffin, 2012). Tujuan spesifik bank syariah dalam menjaga risiko likuiditas adalah untuk menjamin kemampuan dalam memenuhi kewajiban yang jatuh tempo, mendukung pertumbuhan aset berkelanjutan, menekan biaya atas pengelolaan likuiditas, serta menjaga kepercayaan nasabah (Winanti, 2019). Salah satu proksi bagi risiko likuiditas adalah Financing to Deposit Ratio (FDR) (Salamah \& Kusumaningtias, 2019). FDR lebih relevan dipilih karena memiliki kaitan erat dengan pembiayaan bagi hasil yang bank syariah salurkan. FDR mengukur sejauh mana bank syariah menjalankan fungsi intermediasinya dengan menyalurkan pembiayaan dari total dana yang diterima.

Penelitian-penelitian terdahulu menemukan bahwa FDR memiliki dampak positif terhadap peningkatan pembiayaan berbasis bagi hasil maupun PSR (Andriyanto \& Prastika, 2018; Salamah \& Kusumaningtias, 2019). Hasil ini disebabkan karena pembiayaan yang disalurkan juga bedampak kepada pembiayaan bagi hasil. Dengan demikian dapat diajukan hipotesis sebagai berikut:

H2: FDR berpengaruh positif signifikan terhadap PSR. 


\subsubsection{Risiko Pembiayaan}

Risiko pembiayaan adalah suatu risiko yang terjadi akibat kegagalan pihak bersangkutan dalam memenuhi perjanjian yang disepakati (pembiayaan) sesuai kewajibannya. Risiko pembiayaan adalah risiko paling esensial akibat peran bank sebagai lembaga intermediasi dan merupakan risiko paling dominan pada perbankan syariah (Budiman dkk., 2018). Risiko pembiayaan perlu dikawal dengan manajemen risiko yang ketat untuk menjaga kinerja dan kesehatan bank syariah, karena tingginya pembiayaan bermasalah mengharuskan bank syariah menyediakan alternatif dana lain sebagai pengganti untuk menutup kerugian demi mengurangi risiko pembiayaan (Sari, 2016). Risiko pembiayaan umumnya diwakilkan dengan rasio Non Performing Financing (NPF) (Budiman dkk., 2018; dan Salamah \& Kusumaningtias, 2019). Semakin tinggi NPF menunjukkan semakin buruknya kinerja dan kesehatan bank syariah bersangkutan begitupun sebaliknya. Dengan kata lain, semakin tinggi NPF maka semakin tinggi pula risiko pembiayaannya karena disebabkan tingginya pembiayaan bermasalah dari total pembiayaan keseluruhan.

Penelitian terdahulu telah menguji bahwa peningkatan NPF akan berpengaruh terhadap penurunan volume pembiayaan bagi hasil dan juga profit sharing financing ratio karena tingginya NPF akan mengharuskan bank mengurangi risiko dengan menurunkan volume pembiayaan bagi hasil (Andriyanto \& Prastika, 2018; dan Salamah \& Kusumaningtias, 2019). Dengan demikian dapat diajukan hipotesis sebagai berikut: H3: NPF berpengaruh negatif signifikan terhadap PSR.

\subsubsection{Efisiensi Operasional}

Efisiensi operasional dalam bisnis perbankan memiliki peranan penting meningkatkan kinerja keuagan, salah satunya maksimalisasi laba (Syaifudin, 2009). Menurut Syaifudin (2009), Efisiensi operasional menunujukan kemampuan bank dalam mengelola input yang digunakan (biaya operasional) dan output yang dihasilkan (pendapatan operasional). Efisiensi operasional bank syariah dapat dijelaskan dengan rasio Biaya Operasional Pendapatan Operasional (BOPO) (Diantini, Ni Kadek Nita Gunadi, I Gst Ngr Bagus Suarjana, 2020; Karolina dkk., 2020). BOPO atau rasio efisiensi mengukur efisiensi bank syariah dalam kegiatan operasionalnya. Kinerja bank syariah yang baik akan ditunjukkan oleh rendahnya BOPO karena mengindikasikan efisiennya input dan output bisnis perbankan begitupun sebaliknya kurang mampunya bank syariah dalam menambah pendapatan atau menekan biaya operasional akan meningkatkan rasio BOPO yang kemudian dapat menyebabkan kerugian (Diantini, Ni Kadek Nita Gunadi, I Gst Ngr Bagus Suarjana, 2020).

Penelitian-penelitian terdahulu menemukan hubungan pengaruh antara BOPO dengan peningkatan profit sharing financing dan juga volume pembiayaan (Andriyanto \& Prastika, 2018). BOPO atau efisiensi yang meningkat akan juga meningkatkan pembiayaan, karena keberhasilan menekan biaya operasional akan berdampak kepada bank syariah untuk meningkatkan dananya pada pembiayaan produktif (Andriyanto \& Prastika, 2018). Dengan demikian dapat diajukan hipotesis sebagai berikut: H4: BOPO berpengaruh positif signifikan terhadap PSR. 


\section{METODE PENELITIAN}

Penelitian ini menerapkan metode penelitian kuantitatif dengan pendekatan eksplanatori. Tujuan dari pendekatan eksplanatori pada penelitian ini adalah untuk mencari penyebab dan juga alasan serta memberikan bukti untuk mendukung atau menyangkal penjelasan atau prediksi maupun hipotesis untuk menemukan hingga melaporkan hubungan antara aspek fenomena penelitian (Boru, 2018). Jenis data yang diterapkan yaitu data sekunder berupa data panel. Data tersebut bersumber dari halaman website $\mathrm{OJK}, \mathrm{BI}$, serta BUS bersangkutan. Sampel diperoleh melalui purposive sampling dengan kriteria BUS yang telah terdaftar pada OJK dan menerbitkan laporan keuangan sepanjang periode 2015-2019, sehingga didapat 12 sampel.

Teknik analisis yang digunakan yaitu data panel statis atau static panel regression dan data panel dinamis dengan pendekatan Generalised Method of Moments (GMM) untuk melihat konsistensi dan ketahanan variabel dalam estimasi pada waktu yang berbeda. Berikut adalah model estimasi yang dibangun pada model statis.

$$
\mathrm{PSR}_{i t}=\alpha+\beta_{1} \mathrm{DPK}_{\mathrm{it}}+\beta_{2} \mathrm{FDR}_{\mathrm{it}}+\beta_{3} \mathrm{NPF}_{\mathrm{it}}+\beta_{4} \mathrm{BOPO}_{\mathrm{it}}+\mathrm{v}_{\mathrm{it}}
$$

Sedangkan pada model dinamis (GMM) dimana terdapat lag pada setiap variabelnya dapat dijabarkan pada model estimasi berikut.

$\mathrm{PSR}_{\text {it }}=\alpha+\beta_{1} \mathrm{PSR}_{\mathrm{it}-1}+\beta_{2} \mathrm{DPK}_{\mathrm{it}-1}+\beta_{3} \mathrm{FDR}_{\mathrm{it}-1}+\beta_{4} \mathrm{NPF}_{\mathrm{it}-1}+\beta_{5} \mathrm{BOPO}_{\mathrm{it}-1}+\mathrm{v}_{\mathrm{it}}$ Aplikasi atau software yang digunakan sebagai alat analisis statistik adalah eviews 9 dibantu dengan alat pengolah data numerik yaitu Excel 2019. Langkah analisis akan diawali dengan pemilihan model estimasi, dilanjutkan dengan pengujian pemilihan model, dan uji asumsi klasik sampai terciptanya hasil statistik regresi data panel.

\section{HASIL DAN PEMBAHASAN}

\subsection{Pemilihan Model Regresi Statis}

Penelitian menerapkan teknik analisis regresi data panel statis atau static panel regression karena akan mengurangi bias variabel yang dihilangkan (Wooldridge, 2013). Selain itu, analisis regresi data panel sangat cocok untuk penelitian dengan pendekatan eksplanatori (Xu dkk., 2007). Pemilihan model dalam regresi data panel penelitian ini menggunakan 3 model yang umum diterapkan, yaitu Common Effect Model (CEM), Fixed Effect Model (FEM), dan Random Effect Model (REM). Pemilihannya akan didasarkan uji chow, hausman, dan lagrange multiplier: Berikut hasil yang diperoleh pada pengujian tersebut.

Tabel 2

Pemilihan Model Terbaik

\begin{tabular}{|l|l|l|l|l|}
\hline \multicolumn{1}{|c|}{ Pengujian } & \multicolumn{1}{c|}{ Tujuan } & \multicolumn{1}{c|}{ Nilai Statistik } & Probabilitas & Kesimpulan \\
\hline Uji Chow & $\begin{array}{l}\text { Memilih di antara } \\
\text { CEM dan FEM }\end{array}$ & $\begin{array}{l}\text { Chi-square: } \\
197,346\end{array}$ & 0,000 & FEM terbaik \\
\hline Uji Hausman & $\begin{array}{l}\text { Memilih di antara } \\
\text { FEM dan REM }\end{array}$ & $\begin{array}{l}\text { Chi-square: } \\
20,195\end{array}$ & 0,001 & FEM terbaik \\
\hline
\end{tabular}

Sumber: Olahan Penulis 
Berdasarkan tabel 2, dapat diketahui hasil dari pengujian Chow dan Hausman. Pada uji Chow melibatkan dua model regresi yaitu CEM dan FEM dengan kesimpulan bahwa FEM lebih baik dari CEM karena probabilitas chi-squares sebesar 0.000 yang berarti memiliki nilai dibawah batas kritis yaitu 5\%. Oleh karena itu uji pemilihan model akan dilanjutkan pada uji hausman agar dapat menentukan model terbaik. Uji Hausman yang melibatkan FEM dan REM. Berdasarkan hasil analisis, model terbaik untuk digunakan adalah FEM, karena nilai probabilitas chi squares sebesar 0.001 yang dalam artian memiliki nilai di bawah signifikansi 5\%. Pengujian tidak perlu dilanjutkan pada uji lagrange multiplier karena pada uji chow dan uji hausman sudah ditemukan model terbaik yang serupa.

Berikut FEM sebagai estimasi regresi yang terpilih disajikan pada tabel di bawah.

Tabel 3

Model Fixed Effect

\begin{tabular}{lllll}
\hline \hline Variable & Coefficient & Std. Error & t-Statistic & Prob. \\
\hline \hline C & -0.758261 & 0.342293 & -2.215236 & 0.0320 \\
DPK & 0.135997 & 0.038622 & 3.521225 & 0.0010 \\
FDR & 0.000296 & $9.39 \mathrm{E}-05$ & 3.153302 & 0.0029 \\
NPF & -1.600781 & 0.769359 & -2.080667 & 0.0433 \\
BOPO & -0.034654 & 0.032539 & -1.064971 & 0.2927 \\
\hline \hline
\end{tabular}

R-squared $\quad 0.968645$

Adjusted R-squared $\quad 0.957955$

F-statistic $\quad 90.61817$

Prob(F-statistic) $\quad 0.000000$

Sumber: Olahan Penulis

\subsection{Uji Kelayakan GMM}

Untuk mengetahui ketahanan variabel independen terhadap adanya lag waktu dalam estimasi, penelitian ini melakukan pengujian dengan pendekatan regresi data panel dinamis. Regresi data panel dinamis menawarkan keunggulan tambahan daripada regresi data panel statis karena mampu mengatasi heterogenitas dan juga mampu menangani endogenitas variabel model dikarenakan memanfaatkan adanya variabel instrumen (IV) (Labra Lillo \& Torrecillas, 2018). GMM dikembangkan Arrelano dan Bond (Arellano \& Bond, 1991). Metode analisis data panel dinamis penelitian ini menggunakan regresi Generalised Methof of Moments (GMM).

Berikutnya adalah estimasi regresi dengan model Genaralised Method of Moments (GMM) yang melibatkan lag pada setiap variabel dalam estimasi untuk melihat pengaruhnya pada variabel dependen yaitu PSR. 
Tabel 4

Model Generalised Method of Moments (GMM)

\begin{tabular}{ccccc}
\hline \hline Variable & Coefficient & Std. Error & t-Statistic & Prob. \\
\hline \hline PSR(-1) & 0.949264 & 0.072610 & 13.07340 & 0.0000 \\
DPK(-1) & 0.102488 & 0.023317 & 4.395400 & 0.0001 \\
FDR(-1) & 0.000252 & $5.35 \mathrm{E}-05$ & 4.700663 & 0.0001 \\
NPF(-1) & 1.243493 & 0.451516 & 2.754040 & 0.0098 \\
BOPO(-1) & 0.000736 & 0.018556 & 0.039641 & 0.9686 \\
\hline \hline
\end{tabular}

Sumber: Olahan Penulis

Pertama, dievaluasi nilai probabilitas DPK terhadap PSR sebesar 0.0010 (di bawah 5\%) dan koefisien sebesar 0.135997. Diperoleh hal serupa pada model GMM, didapat nilai probabilitas 0.0001 (di bawah 5\%) dan nilai koefesien sebesar 0.102488. Sehingga pada model GMM, DPK(-1) juga memiliki pengaruh positif signifikan terhadap PSR. Dapat disimpulkan bahwa hipotesis pertama penelitian ini diterima.

Kedua, diperoleh nilai probabilitas FDR terhadap PSR adalah sebesar 0.0029 (di bawah 5\%) dan koefesien sebesar 0.000296. Pada model GMM, FDR(-1) terhadap PSR diketahui mendapat nilai probabilitas sebesar 0.0001 (di bawah 5\%) dan koefesien sebesar 0.000252. Hal ini berarti FDR(-1) memiliki pengaruh positif siginifikan terhadap PSR. Dapat disimpulkan bahwa hipotesis kedua penelitian ini diterima.

Ketiga, diketahui bahwa nilai probabilitas NPF terhadap PSR adalah sebesar 0.0433 (di bawah 5\%) dan koefesien sebesar -1.600781. Hasil berbeda diperoleh pada model GMM. Didapat nilai probabilitas NPF(-1) terhadap PSR adalah sebesar 0.0098 (di bawah 5\%) dan koefisien sebesar 1.243493. Sehingga NPF(-1) berpengaruh positif signifikan terhadap PSR. Dapat disimpulkan bahwa hipotesis kedua penelitian ini diterima.

Keempat, ditemukan nilai probabilitas BOPO terhadap PSR sebesar 0.2927 (di atas 5\%) dan nilai koefesien sebesar -0.034654 . Pada model GMM, diperoleh nilai probabilitas BOPO(-1) yang jauh lebih tinggi sebesar 0.9686 (di atas 5\%) dan koefesien sebesar 0.000736 sehingga disimpulkan bahwa $\mathrm{BOPO}(-1)$ berpengaruh positif tidak signifikan terhadap PSR. Dapat disimpulkan bahwa hipotesis keempat pada penelitian ini ditolak.

\subsection{Pembahasan}

Analisis statistik telah menunjukkan adanya perngaruh positif signifikan DPK terhadap PSR. Baik pada model statis (fixed effect) maupun dinamis (GMM), DPK tetap menunjukkan perilaku yang serupa terhadap PSR. Hal ini menggambarkan pola konsisten DPK dalam pengaruh positifnya terhadap PSR dan tentunya memperjelas hubungan antar dua variabel ini. DPK yang menjalankan fungsi funding memiliki kontribusi efektif terhadap peningkatan pembiayaan mudharabah dan musyarakah Bank Umum Syariah (BUS). Hasil ini memastikan secara konsisten setiap kenaikan Dana Pihak Ketiga (DPK) BUS baik pada tahun sebelumnya dan tahun berjalan akan berdampak kepada kenaikan Profit Sharing Financing Ratio (PSR) tahun berjalan yang artinya 
meningkatkan juga islamicity performance index. Dapat ditarik kesimpulan bahwa BUS secara kuat meningkatkan porsi pembiayaan musyarakah dan mudharabah kepada masyarakat setiap tahunnya akibat aliran Dana Pihak Ketiga (DPK). Selain itu, hasil ini juga memberikan indikasi bahwa DPK telah memainkan peran penting dalam menjalankan fungsi financing BUS. Hasil ini sejalan dengan penelitian sebelumnya dalam menganalisis hubungan DPK dengan PSR maupun dengan pembiayaan bagi hasil yang dilakukan Aprilia \& Mahardika (2019), dan Lisa (2017). Maka dari itu penelitian ini juga memperkuat hubungan DPK dengan PSR.

Terciptanya hubungan positif signifikan antara FDR dengan PSR pada model fixed effect diperkuat dengan hasil konsisten pengaruh positif FDR terhadap PSR pada model GMM. FDR terhadap PSR pada model dinamis maupun statis memiliki korelasi paling rendah dibandingkan variabel signifikan lainnya. Timbulnya korelasi yang lemah secara konsisten dari FDR terhadap PSR membuktikan bahwa fungsi financing yang dilakukan BUS sejauh ini masih didominasi oleh pembiayaan selain mudharabah dan musyarakah. Sejauh ini dominasi tertinggi pada FDR masih terpusat pada pembiayaan berbasis jualbeli (murabahah) karena memiliki dampak yang jauh lebih besar terhadap profitabilitas. FDR yang diperoleh BUS sendiri selama periode 2015-2019 masih dalam batas aman dengan fluktuasi dibawah 89\% sehingga BUS sejauh ini dinyatakan mampu mengendalikan likuiditasnya ditengah peningkatan porsi pembiayaan bagi hasil. Hasil ini memperkuat penelitian studi Andriyanto \& Prastika (2018) dalam kaitannya dengan hubungan FDR terhadap pembiayaan bagi hasil. Oleh karena itu, hasil ini juga menolak studi sebelumnya yang dilakukan oleh Salamah \& Kusumaningtias (2019) dimana FDR tidak memiliki dampak terhadap PSR.

Hubungan NPF terhadap PSR pada penelitian ini memiliki hasil yang tidak konsisten. Pada model statis, terjadi pengaruh negatif signifikan sedangkan pada model dinamis justru sebaliknya terjadi pengaruh positif signifikan. Namun kontribusi NPF terhadap perubahan nilai PSR sangatlah penting dan diperhitungkan karena nilai korelasinya cukup tinggi. Korelasi yang tinggi antara NPF dengan PSR menunjukkan bahwa dominasi pembiayan bermasalah berasal dari pembiayaan mudharabah atau musyarakah. BUS tetap termotivasi untuk terus meningkatkan pembiayaan mudharabah atau musyarakah setiap tahunnya meskipun terjadi peningkatan NPF ditahun sebelumnya. Hal ini dikarenakan selama periode 2015-2019 NPF yang diperoleh BUS masih dalam batas aman kurang dari $4 \%$. Namun, BUS akan tetap melakukan hal sebaliknya yaitu menurunkan rasio PSR pada peningkatan NPF di tahun berjalan. Hal ini akan dilakukan BUS tentunya untuk mengontrol risiko pembiayaan agar tetap dibawah batas wajar dan menghindari meningkatnya Penyisihan Penghapusan Aktiva Produktif (PPAP) yang akan mengurangi modal (Wahab, 2014). Hasil ini mendukung dengan penelitian sebelumnya oleh Laksmi Puteri \& Solekah (2018) bahwa NPF tidak berpengaruh terhadap pembiayaan murabahah yang merupakan pembiayaan dominan dalam pelaksanaan financing BUS. Penelitian ini memperkuat temuan Andriyanto \& Prastika (2018) dan Salamah \& Kusumaningtias (2019) mengenai hubungan NPF terhadap PSR ataupun pembiayaan mudharabah dan musyarakah. 
Dampak BOPO terhadap PSR pada model statis menunjukkan hubungan negatif sedangkan model dinamis menunjukkan hubungan positif. Meskipun seperti itu, hasil tersebut tetap tidak dapat dilibatkan secara statistik karena baik pada model statis maupun pada model dinamis menunjukkan tidak adanya signifikansi hubungan kedua variabel tersebut. Kecenderungan peningkatan pada fluktuasi rasio BOPO dalam beberapa tahun terakhir yang diperoleh BUS tidak memiliki dampak signifikan terhadap PSR. Meskipun PSR sempat terhambat pertumbuhannya ditahun 2017, PSR selalu menunjukkan peningkatan positif selama periode 2015-2019. BUS tetap melakukan peningkatan proporsi pembiayaan bagi hasil, terlepas dari fluktuasi rasio BOPO. Dengan demikian, temuan penelitian ini bertolak belakang dengan Prastika Andriyanto \& Prastika (2018) dalam kaitannya dengan dampak $\mathrm{BOPO}$ terhadap pembiayaan musyarakah atau mudharabah.

Secara simultan, pengaruh seluruh variabel bebas yang dibangun pada model ini yaitu DPK, FDR, NPF, serta BOPO menunjukkan pengaruh kuat terhadap variabel terikat yaitu PSR sebesar $95.7955 \%$. Distribusi korelasi yang dibangun dari keempat variabel tersebut belum mencapai nilai yang proporsional. DPK dan NPF berkontribusi jauh lebih besar dibandingkan dua variabel lainnya yaitu FDR dan BOPO. FDR memiliki pengaruh yang terlampu rendah dari dua variabel dominan tersebut, terlebih untuk variabel BOPO tingkat kepercayaan berada jauh dibawah 95\% yang berarti dampaknya terhadap PSR masih belum bisa dipastikan.

Korelasi kuat dan signifikan pada model dinamis antara PSR tahun sebelumnya terhadap PSR tahun berjalan memberikan arah polarisasi BUS terkait tindakannya dalam melaksanakan fungsi financing. BUS secara kuat termotivasi untuk selalu meningkatkan PSR dari tahun ketahun secara konsisten sejauh ini. Hal ini mengindikasi BUS baik secara materialistik maupun non-materialistik memperoleh manfaat dengan meningkatkan porsi pembiayaan mudharabah dan musyarakah. Dengan kata lain, tren yang meningkat dari PSR memberikan dampak positif sehingga BUS terdorong untuk selalu meningkatkan porsi pembiayaan berbasis bagi hasil. Dengan kata lain, tren peningkatan pembiayaan mudharabah dan musyararakah akan berdampak kepada peningkatan pembiayaan serupa di tahun berikutnya.

\section{PENUTUP}

Temuan penelitian menyimpulkan bahwa konsistensi hubungan pada model fixed effect dan GMM terjadi pada variabel DPK dan FDR. perubahan kedua variabel mempengaruhi tingkat PSR meskipun pada waktu yang berbeda. BUS menjalankan fungsi funding dan financing dengan baik sejauh ini, meskipun financing masih terfokus pada pembiayaan diluar mudharabah dan musyarakah. Pada variabel NPF, terjadi perbedaan perilaku karena inkonsistensi arah hubungan pada model fixed effect dan GMM. BUS menerapkan perilaku yang fleksibel dalam meningkatkan porsi pembiayaan berbasis bagi hasil yang ditinjau dari perubahan nilai NPF disebabkan dominasi pembiayan bermasalah yang berasal dari pembiayaan bagi hasil. Variabel lainnya yaitu BOPO tidak memiliki signifikansi terhadap PSR yang artinya BUS tidak mempertimbangkan nilai BOPO dalam menentukan porsi pembiayaan bagi hasil. Secara 
simultan, seluruh variabel bebas dapat menjelaskan PSR sebesar $95.7955 \%$. Selain itu, ditemukan juga bahwa tren peningkatan PSR setiap tahun dipengaruhi oleh PSR tahun sebelumnya sehingga BUS diindikasi mendapatkan dampak positif dari setiap peningkatan nilai PSR.

Penelitian ini berimplikasi kepada faktor penentu dalam kaitannya dengan Islamicity Performance Index (IPI). Nilai Socio-Economic BUS berkaitan erat dengan bagaimana BUS menjalankan fungsi funding dan financing nya. Pengelolaan risiko likuiditas sangat diperlukan. Semakin tinggi keduanya, maka semakin baik pula IPI. Maka dominasi pembiayaan murabahah perlu ditekan diiringi dengan konsistensi peningkatan pembiayaan mudharabah dan musyarakah. Disamping itu, peningkatan pembiayaan bermasalah juga menjadi faktor penghambat utama peningkatan nilai IPI sehingga diperlukan pengelolaan yang baik untuk menjaga kestabilannya. Terakhir, penelitian ini juga menekankan pentingnya BUS menjaga tujuan utamanya untuk selalu memberikan dampak sosial kepada masyarakat selain hanya mengejar profitabilitas.

Penelitian ini hanya menggunakan variabel PSR untuk memproksi IPI, sehingga diharapkan penelitian selanjutnya untuk menambah variasi variabel lainnya dari IPI. Selain itu, objek penelitian ini hanya melibatkan BUS, sehingga belum dapat menggeneralisasikan perbankan secara keseluruhan. Diperlukan ekspansi untuk melibatkan UUS maupun BPRS. Terakhir, variabel determinan IPI yang digunakan pada penelitian ini terbatas menyertakan variabel yang berasal dari faktor internal bank saja. Maka dari itu, penelitian berikutnya dapat menyertakan variabel dari faktor eksternal bank.

\section{DAFTAR PUSTAKA}

Abdul Razak, D., \& Abdul-Wahab, A.-H. (2018). Promoting a Sharing Economy in the Islamic Finance Industry: A Study of Selected Oic Countries. International Journal of Islamic Economics and Finance, 1(1).

Andriyanto, I., \& Prastika, A. I. (2018). Pengaruh Rasio Kesehatan Bank Terhadap Volume Pembiayaan Bank Umum Syariah Di Indonesia. Journal of Islamic Banking and Finance, 2(1), 1-16.

Aprilia, S., \& Mahardika, D. P. K. (2019). Faktor Yang Mempengaruhi Pembiayaan Bagi Hasil Pada Bank Umum Syariah Di Indonesia. Jurnal Riset Akuntansi Kontemporer, 11(1), 9-15.

Arellano, M., \& Bond, S. (1991). Some Tests of Specification for Panel Data: Monte Carlo Evidence and an Application to Employment Equations. Review of Economic Studies, 58(2), 277-297.

Ariffin, N. M. (2012). Liquidity Risk Management And Financial Performance In Malaysia: Empirical evidence from Islamic banks. Aceh International Journal of Social Sciences, 1(2), 68-75.

Ascarya, A., \& Yumanita, D. (2006). The Lack of Profit and Loss Sharing Financing in Indonesian Islamic Banks: Problems and Alternative Solutions. Paper presented at the INCEIF Islamic Banking and Finance Educational Colloquium, KL Convention Center, Kuala Lumpur, Malaysia. 
Ayyubi, E., Anggaraeni, L., \& AD, M. (2017). Pengaruh Bank Syariah terhadap Pertumbuhan Ekonomi di Indonesia The Effect of Islamic Banking to Economic Growth in Indonesia. Jurnal Al-Muzara'ah, 5(2).

Boru, T. (2018). Chapter Five Research Design And Methodology 5.1. Introduction Research Methodology. Dalam University of South Africa, PHD Thesis. University of South Africa.

Budiman, R., Achsani, N. A., \& Ismal, R. (2018). Risiko Pembiayaan dan Determinannya pada Perbankan Syariah di Indonesia. Jurnal Aplikasi Manajemen dan Bisnis, 4(1), 151-159.

Diantini, Ni Kadek Nita Gunadi, I Gst Ngr Bagus Suarjana, I. W. (2020). Pengaruh Capital Adequacy Ratio (CAR), Efisiensi Operasional (BOPO), Risiko Bisnis, Dan Loan To Deposit Ratio (LDR) Terhadap Kinerja Keuangan (Studi Empiris Pada Perusahaan Perbankan Yang Terdaftar Di Bursa Efek Indonesia Tahun 20152017). Emas, 1(1).

El-Biraika, A. (1998). The 1997-1998 East Asian Financial Crises, an Islamic Perspective. Working Paper Economic Research Forum. Working Paper Economic Research Forum.

Ganga, Ms. M., Kalaiselvan, Mr. P., \& Suriya, Ms. R. (2015). Evaluation of Financial Performance. International Journal of Scientific and Research Publications, 5(4).

Hackett, C., Connor, P., Stonawski, M., \& Skirbekk, V. (2015). The Future Of World Religions: Population Growth Projections, 2010-2050: Why Muslims Are Rising Fastest And The Unaffiliated Are Shrinking As A Share Of The World's Population. Pew Research Center.

Hafizh, M., Hidayah, N., \& Silalahi, P. R. (2020). Macroeconomics And Profit Sharing Financing In Islamic Banking In Indonesia: The Third Parties Fund As Intervening. Jurnal Akuntansi dan Keuangan Islam, 8(2), 131-147.

Hameed, S., Wirman, A., Alrazi, B., Nor, M. N. M., \& Pramono, S. (2004). Alternative Disclosure And Performance Measures For Islamic Banks. Proceeding of Second Conference on Administrative Science: Meeting The Challenges of The Globalization Age.

Harahap, D. (2017). Determinan Dana Pihak Ketiga Bank Syariah di Indonesia: Model Vector Autoregresive. Iqtishadia, 10(1).

IFCI. (2019). Global Islamic Finance Report-Islamic Finance Country Index 2019.

Islamic Financial Service Board. (2005). IFSB-1 Guiding principles of risk management for institutions (other than insurance institutions) offering only Islamic financial services. Dalam Islamic Financial Service Board (Nomor December). Islamic Financial Services Board.

Karolina, Nuryani, A., \& Hidayat, A. (2020). Pengaruh Efisiensi Operasional, Kecukupan Modal, Risiko Kredit Terhadap Dana Pihak Ketiga Pada PT Bank Perkreditan Rakyat Di Wilayah Tangerang. Jurnal Ilmiah Prodi Manajemen Universitas Pamulang, 4(2), 112-128.

Khan, M., \& Bhatti, M. (2008). Islamic banking and finance: On its way to globalization. Managerial Finance, 34, 708-725. 
Kinanti, R. Ayu., \& Purwohandoko. (2017). Influence Of Third-Party Funds, CAR, NPF, And FDR Towards The Return On Assets Of Islamic Banks In Indonesia. Jurnal Akuntansi Manajemen, 14(2), 135-143.

Labra Lillo, R., \& Torrecillas, C. (2018). Estimating dynamic Panel data. A practical approach to perform long panels. Revista Colombiana de Estadística, 41(1), 31-52.

Laksmi Puteri, S. I., \& Solekah, N. A. (2018). Pengaruh Pembiayaan Murabahah Dan Musyarakah Melalui Kredit Bermasalah Terhadap Likuiditas Bank Umum Syariah. El Dinar, 6(1), 1. https://doi.org/10.18860/ed.v6i1.5450

Lisa, O. (2017). Analysis Macroeconomic On Islamicity Performance Index Through Fund Third Parties The Islamic Cooperation. International Journal of Social Science and Business, 1(1), 38-46.

Mannan, M. A. (1989). Ekonomi Islam Teori dan Praktek Seri terjemahan.

Murni, Y., Astuti, T., \& Nisa, C. (2018). Determinants of Profit Sharing Financing and Zakat Distribution Based on CAMEL Analysis. Jurnal Keuangan dan Perbankan, 22(4), 760-768.

Presendorfer, J., \& Lehner, O. (2016). Islamic Banking and Finance as an Ethical Alternative: A Systematic Literature Review. ACRN Oxford Journal of Finance and Risk Perspectives, 5(2), 42-64.

Salamah, S. A., \& Kusumaningtias, R. (2019). Pengaruh Corporate Governance Dan Manajemen Risiko Terhadap Islamicity Performance Index Pada Bank Umum Syariah Tahun 2014-2018. Jurnal Akuntansi Unesa, 8(1).

Sari, M. K. (2016). Determinants of Islamic commercial banks financing risk in Indonesia. Journal of Islamic Economics Lariba, 2(2).

Setyowati, R. (2017). Rasionalitas Pendekatan Sharia Compliance dalam Meningkatkan Kepercayaan Nasabah Perbankan Syariah. Jurnal Hukum Ekonomi Islam, 1(1), 1-20.

Syaifudin, D. T. (2009). Efisiensi dan Kinerja Bank (Aplikasi Teori Hubungan Struktural). Unhalu Prees.

Wahab, W. (2014). Analisis Pengaruh Fdr, Npf, Tingkat Bagi Hasil, Kualitas Jasa Dan Atribut Produk Islam Terhadap Tingkat Pembiayaan Mudharabah Pada Bank Umum Syari'Ah Di Semarang. Economica: Jurnal Ekonomi Islam, 5(2), 107-136.

Winanti, W. (2019). Manajemen Risiko Likuiditas Pada Perbankan Syariah. Eksisbank: Ekonomi Syariah Dan Bisnis Perbankan, 3(1), 81-90.

Wooldridge, J. M. (2013). Introductory Econometrics: A Modern Approach, 5th Editon. Thomson South-Western.

Xu, H., Hwan Lee, S., \& Ho Eom, T. (2007). Introduction to Panel Data Analysis. 